\title{
Forest-friendly pedagogy (PeRIMBA) at indigenous school : risk and risk perceptions
}

\author{
Mohd. Najib Haron ${ }^{1}$, Rozilah Kasim ${ }^{1}$, Nur Bahiyah Abdul Wahab ${ }^{2}$, Sharifah Nurulhuda Tuan Mohd \\ Yasin $^{3}$, Siti Aminah Kusin ${ }^{1}$ \\ ${ }^{1}$ Universiti Tun Hussein Onn Malaysia, Malaysia \\ ${ }^{2}$ Institut Pendidikan Guru Kampus Temenggong Ibrahim, Malaysia \\ ${ }^{3}$ Politeknik Sultan Mizan Zainal Abidin, Malaysia
}

\begin{tabular}{l}
\hline \hline Article Info \\
\hline Article history: \\
Received Jan $11^{\text {th }}, 2020$ \\
Revised Feb $12^{\text {th }}, 2020$ \\
Accepted Mar $22^{\text {rd }}, 2020$ \\
\hline
\end{tabular}

\section{Keyword:}

Risk,

Risk Perception,

Teaching and Learning,

Forest School and Pedagogy

\begin{abstract}
The Forest-friendly pedagogy (PeRIMBA) refers to the implementation of outdoor learning session by using forest elements as the learning aid and site. There are four basic principles of PeRIMBA which known as supportive environment, task divided into small portions, the usage of natural surroundings and the involvement of all the senses. The implementation of PeRIMBA introduces a risk-taking approach that will offer the opportunities for teachers and students to engage in risky activities during learning session. This risky activity may seem daunting but if the risks are well managed, the learning sessions will be meaningful. In promoting meaningful learning especially to the indigenous school, Malaysia Ministry of Education support and highlight two intervention action plan that promote flexible classroom and fun learning. Flexible curriculum delivery is not dependent on classroom learning only and fun learning promotes the integration and application of forest elements. However, this intervention action plan needs further research and study especially in the field of risk. The emergence of a social science perspective in the field of risk research has opened up new perspectives to define, measure, and explain the concept of risk. Some of the new risk components proposed in social science studies such as shock, threat, danger, lack of control, and uncertainty. Moreover, the fear and unknown factors are components that influence the perceptions of risk. The input on risk and risk perception will be an added value to teachers to implement PeRIMBA in their teaching and learning sessions. These concepts then lead to risk perception that, in turn, influenced risk assessment and risk management.
\end{abstract}

(C) 2020 The Authors. Published by Redwhitepress.

This is an open access article under the CC BY-NC-SA license

(https://creativecommons.org/licenses/by-nc-sa/4.0/

\section{Corresponding Author:}

Mohd.Najib Haron,

Universiti Tun Hussein Onn Malaysia

Email: mohdnajibharon@gmail.com

\section{Introduction}

The concept of a forest school that conducts learning sessions in the natural environment inspires teachers' creativity by optimizing the use of space and resources in the forest as teaching materials. This shows that the concept of the forest school is more practical and appropriate for children's development. Forestfriendly pedagogy (PeRIMBA) adapted from forest school concept is an increasingly popular pedagogical approach in Malaysia. According to Nur Bahiyah (2015), PeRIMBA was developed based on elements of approach and learning environment. The approach is taking into account of learning outside the classroom environment. The natural environment also known as the forest area (LR) is not confined to the forest 
environment only. Any location that is in contact with the natural environment and is outside the learning norm of the students are considered as an LR but it is a good opportunity if the LR is in the forest. It is also supported by Harris (2017), who stated that LRs can be developed by teachers in a variety of learning environments such as around the school, playground and around their residence.

\section{Forest-Friendly Pedagogy (PeRIMBA)}

Coates \& Pimlott-Wilson (2019), stated that teachers need to act as facilitators by creating an appropriate learning environment for students so that they will be able to experience learning experiences and enhance existing knowledge through the combination of playing and learning methods. According to him, the findings of this study are significant because they not only taking into account the contribution of social constructivist playing pedagogy underlying PeRIMBA-oriented pedagogy but also emphasize on the special need of primary school teachers to see how playing method is a very effective pedagogy. These findings are in line with O'Brien \& Murray (2007), Maynard (2007), Waite (2011), Harris (2017), and Waite and Goodenough (2018) which suggested that playing activities will stimulate students through learning experiences outside the classroom.

According to Coates \& Pimlott-Wilson (2019a) in their study they stated that there are four basic principles of PeRIMBA-oriented pedagogy that are: i) a supportive environment, ii) task divided into small portions, iii) usage of natural surroundings and iv) involvement of all the senses. The small group collaborative activity emphasized in PeRIMBA is also in line with Waite's (2011) statement in which he found that pupils are more likely to master a task if they are divided into smaller groups and scopes. According to him, the first experience of being in the jungle using all their senses is something students can enjoy and is a key factor in increasing their motivation and confidence level. Figure 1 shows basic principles of PeRIMBA adapted from Coates \& Pimlott-Wilson (2019).

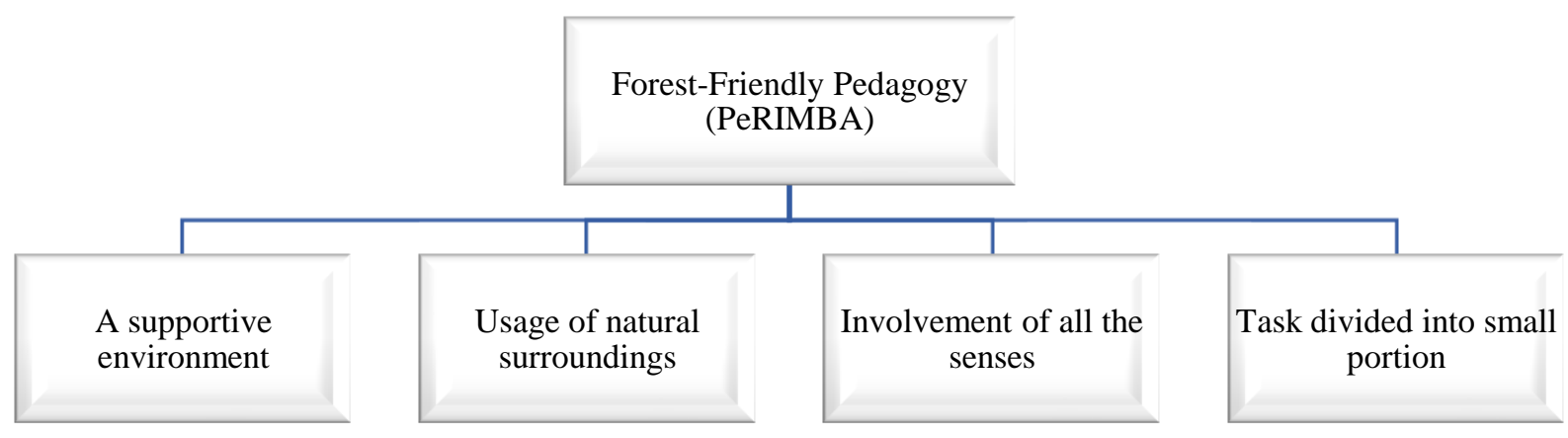

Figure 1 : Basic principles of PeRIMBA adapted from Coates \& Pimlott-Wilson (2019).

\section{Implementation of PeRIMBA in SK Asli}

The Malaysian Education Development Plan 2013-2025 under Initiative \# 57: Indigenous and Indigenous Education Transformation is implemented to ensure equity, that the equitable access of Indigenous and Indigenous student education along with mainstream education can be realized with the determination and commitment of all parties. The Malaysian Education Development Plan Wave 2 (2016-2020) saw efforts to improve learning outcomes and curriculum standards for all Indigenous students as they were implemented using specially designed interventions. Among the major highlights of this intervention plan are: 1) Flexible curriculum delivery is not dependent on classroom learning only (Flexible Classroom); 2) A Fun Learning Approach that promotes the integration and application of forest elements.

Delivering a more flexible curriculum using the classroom-based education approach by incorporating forest-friendly elements is a key focus of the implementation of this intervention as it offers Indigenous students the opportunity to gain experience and knowledge through activities conducted directly related with their surrounding environment. This demonstrates that the concept of the School of Forestry which adopts a more practical approach through direct activities with the environment or better known as PeRIMBA is appropriate for children's development. According to (Nordin \& Ahmad, 2015), the indigenous peoples rigorous and ever-moving lifestyle for their survival appears to be more synonymous with the implementation of PeRIMBA. Studies conducted by Nur Bahiyah, Maryati, Azman and Mohd. Najib (2013) found that interactions between education and the environment can enhance Indigenous students' competence. 
As such, PeRIMBA is a key force behind the Special Needs and Indigenous Student Intervention Programme. These interventions guide teachers to apply the concept of an off-the-classroom approach using the Fun Learning approach by encouraging the integration and application of the forest elements. This is supported by Nordin \& Ahmad (2015) in their study found that Aboriginal students are very happy and interested in engaging in teaching and learning activities using the Fun Learning approach.

\section{Method}

The purpose of this study is to identify risk and risk perceptions' element for forest-friendly pedagogy (PeRIMBA) at Indigenous School. To achieve this goal, this study is conducted qualitative in the form of analysis document. A few of previous survey report, conference proceeding, and journal had been referred as literature study, and analysed with data gathered use schedule matric (Strauss \& Corbin, 1990). According to Sallabas (2013) and Best \& Kahn (1998), method analysis document is the most suitable tool for collection of information in qualitative study. Apart from that, Onwuegbuzie et al. (2012) believe that variable related to the topic can be identified by doing research again towards literature study. This technique used, because it is method that is orderly to observe and evaluate document and electronic resource.

\section{Results and Discussions}

\section{Risk}

Jacoby, Kaplan, \& Szybillo, (1974) have developed a taxonomy of "losses" in the areas of risk such as financial loss, performance loss, physical loss, psychological loss, social loss, and time loss. According to them, in one situation, risk can be present in five factors namely financial, performance, physical, psychological and social. Psychological and social risks are usually combined and considered as psychosocial risks. These 5 dimensions can be considered as standing independently (functionally independent) so that when one type of risk increases, the other variant can increase, decrease or remain unchanged and they function independently where they affect each other (remain unaffected). Figure 2 shows the taxonomic loss from the angle of risk introduced by Jacoby, Kaplan, \& Szybillo, (1974)

Table 1: Taxonomy of risk-based losses by Jacoby, Kaplan, \& Szybillo, (1974)

\begin{tabular}{|c|c|c|}
\hline $\begin{array}{c}\text { Type of Perceived } \\
\text { Risk }\end{array}$ & Operational Definition & Anchor Points \\
\hline 1.Financial Risk & $\begin{array}{l}\text { What are the chances that you stand to lose money if } \\
\text { you try an unfamiliar brand of } \\
\text { it won't work at all, or because it costs more than it } \\
\text { should to keep it in good shape)? }\end{array}$ & $\begin{array}{l}\text { 1=low chance of losing } \\
\text { money; } 9=\text { high chance of } \\
\text { losing money }\end{array}$ \\
\hline 2.Performance Risk & $\begin{array}{l}\text { What is the likelihood that there will be something } \\
\text { wrong with an unfamiliar brand of __ or that it } \\
\text { will not work properly? }\end{array}$ & $\begin{array}{l}1=\text { low functional risk; } \\
9=\text { high functional risk }\end{array}$ \\
\hline 3.Physical Risk & $\begin{array}{l}\text { What are the chances that an unfamiliar brand of } \\
\text { may not be safe; i.e., may be (or become) } \\
\text { harmful or injurious to your health? }\end{array}$ & $\begin{array}{l}1=\text { very } \quad \text { safe; } \quad 9=\text { very } \\
\text { unsafe }\end{array}$ \\
\hline 4.Psychological Risk & $\begin{array}{l}\text { What are the chances that an unfamiliar brand of } \\
\text { will not fit in well with your self-image or } \\
\text { self-concept (i.e., the way you think about yourself)? }\end{array}$ & $\begin{array}{l}1=\text { low psychological risk; } \\
9=\text { high psychological risk }\end{array}$ \\
\hline 5.Social Risk & $\begin{array}{l}\text { What are the chances that are unfamiliar brand of } \\
\text { will affect the way others think of you? }\end{array}$ & $\begin{array}{l}\text { 1=low social risk; } 9=\text { high } \\
\text { social risk }\end{array}$ \\
\hline $\begin{array}{l}\text { 6.Overall Perceived } \\
\text { Risk }\end{array}$ & $\begin{array}{l}\text { On the whole, considering all sorts of factors } \\
\text { combined, about how risky would you say it was to } \\
\text { buy an unfamiliar brand of __? }\end{array}$ & $\begin{array}{l}1=\text { not risky at all; } \\
9=\text { extremely risky }\end{array}$ \\
\hline
\end{tabular}

According to Kasperson et al., (1988) the concept of "risk" in social science studies combines ideas of individual assessment and uncertainty. The emergence of a social science perspective in the field of risk research has opened up new perspectives to define, measure, and explain the concept of risk. Some of the new risk components proposed in social science studies such as shock, threat, danger, lack of control, and uncertainty. Social science studies do not deny the concept of loss in economics but rather include it in contexts related to ideas of control and uncertainty. These ideas outline the ways in which risk is associated with human experience or in other words subjective. From this perspective, risk cannot be defined solely on 
the basis of activities or events, but rather should be seen in the human experience and the social environment in which the events occur.

Risk can involve physical, psychological, social or economic harm as a result of participation in research, and can vary from minimal to severe: 1) Physical risks: These risks include any bodily harm, ranging from minor or serious harm that may be temporary or permanent. The risks may also occur immediately or be delayed; 2) Psychological risks: The participant may suffer emotional discomfort or anxiety, develop a sense of shame or a negative perception of self, or develop thought and behavioural aberrations; 3) Social risks: The participant may be exposed to discrimination or to social stigmatisation in the workplace or in social life. (For example, a research participant applies for health insurance after participation in an HIV vaccine trial, but is penalised because he/she now has antibodies for HIV and tests positive; 4) Economic risks: The participant incurs direct or indirect financial costs due to participation in the research project.

\section{Risk perceptions}

According to Renn (1998) risk refers to the likelihood of actions or events affecting human judgment. The term risk refers to the same element of danger but reality and the possibility of making a difference in people's perception of risk. According to him, there are 3 elements at risk: i) outcomes that influence human judgment, ii) probability of occurrence (uncertainty) and iii) formula for combining the two elements.

Knowledge of danger plays an important role in the study of risk as it shapes people's perceptions of risk. Johnson (1993) has presented a list of factors that could potentially influence people's perceptions of risk: 1) Fear (Dread), Familiarity: Fear is characterized by a lack of control, a scary potential and the effects of death and usually refers to the amount of knowledge and / or exposure that an individual has; 2) Possible incident: Individual determination of potential risks; 3) Dangerous impact: Possible positive and negative effects; 4) Social networks, religious beliefs and ideologies: Opinions from friends, family, religious teachings, or people at work or neighbourhood network.

The Johnson category has a significant overlap with the risk elements. For example, Renn's (1988) "probability of occurrence" is Johnson's concept of the "likelihood of occurrence". In addition, the concepts of shock, threat, danger, lack of control, uncertainty, and social networks are also listed in Johnson's category. The fear and unknown factors are components that influence perceptions of risk. Johnson's category can also be reduced to fear and habit. Possible causes and perceptions of harmful outcomes are both individual evaluations determined by the fear factor. Social networks, religious beliefs, and ideologies (cultures) are part of the basic knowledge of the individual which is part of the norm. This also means that Johnson's four original categories can be divided into two categories: fear and habit. Figure 3 shows the factors that influence people's perception of risk.

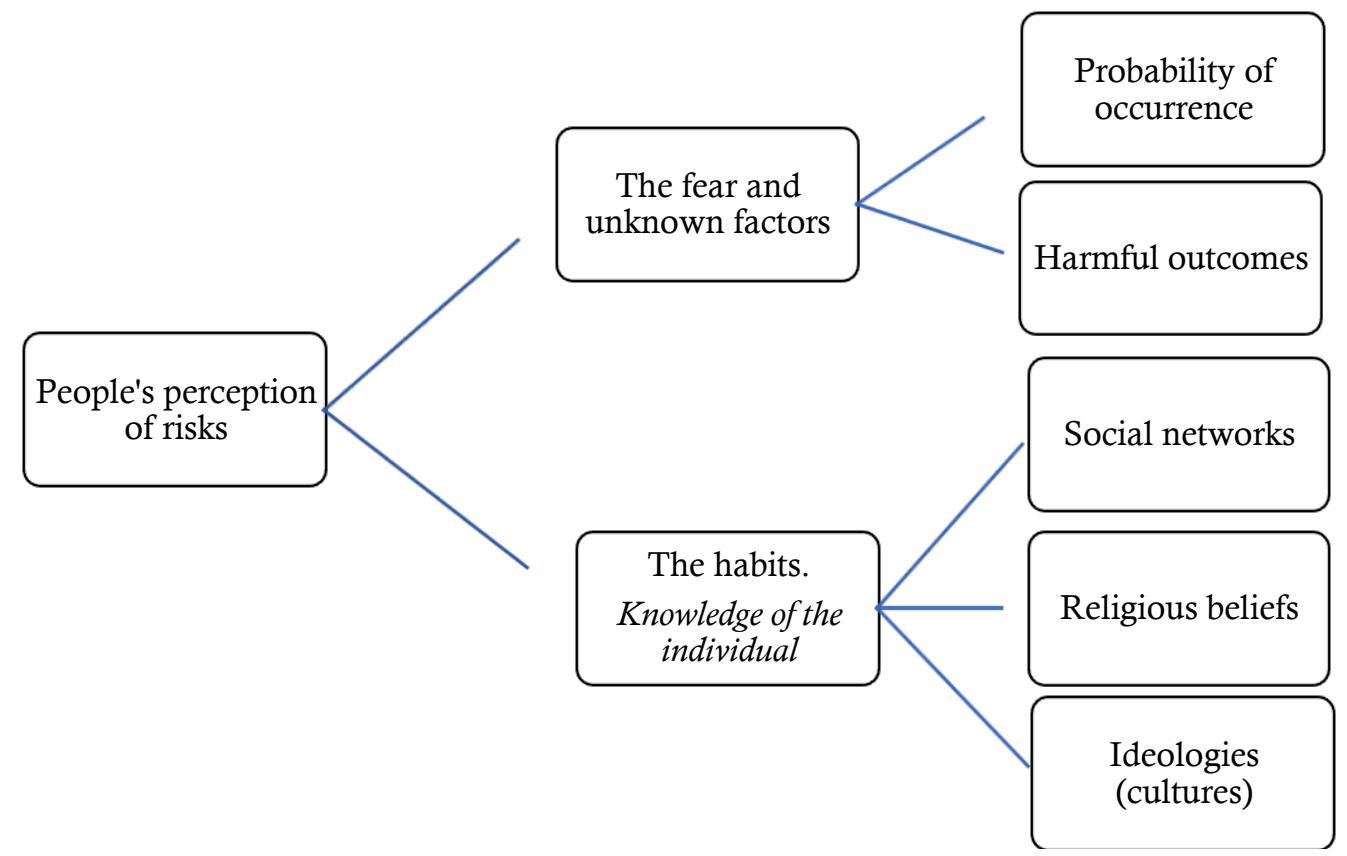

Figure 2: The framework of people's perception of risk. 
Risk and Perceptions of PeRIMBA Risk in SK Asli

Researchers use the word "risk" in the context of PeRIMBA to indicate situations where teachers and students can identify and evaluate potential danger and make actionable decisions. This is different from using the same words to describe the dangers that teachers and students are unable to evaluate for themselves and that have no clear benefit. Therefore, in this paper, risk is defined as a beneficial risk and at the same time may result in losses which are the likelihood of physical injury (physical risk) and emotional discomfort (psychological risk) : 1) Physical risk: This risk includes any harm to the body. This risk can be measured from the risk of a minor injury (minor injury) to a serious (fractured) risk that may be temporary or permanent in the body. This risk can also be caused by mismanagement of equipment or weather factors that affect the environment. This risk can be immediate or delayed; 2) Psychological risk: Participants may experience emotional distress such as negative perceptions of themselves (fear, shame).

Risk often defined as a combination of probabilities and the frequency of several potential dangers. According to Harris (2017), physical and psychological risks are clearly contributed by the danger during the implementation of PeRIMBA-oriented pedagogy. According to him, participating in PeRIMBA-oriented pedagogy gives participants the potential for injury (physical risk) and emotional discomfort, namely fear and anxiety (psychological risk). Risk severity rates can change from minimum to maximum or vice versa.

According to Connolly \& Haughton, (2017) the term "risk" refers to two things: risk-taking or riskaversion. Avoidance of risk refers to the society's extreme concern for the protection of children due to the influence of the modern world which caused danger to external activities that may contribute to physical and psychological risks and thus neglect opportunities for children to be independent. Taking risks can mean different things where the dangers of doing risky external activities are considered beneficial. He quoted the Prime Minister's words at the time as declaring that "risk" was leading to a 'poisoning of the relationship between adults and children' (Cameroon 2008).

According to Stan \& Humberstone (2011), there are many perceptions of "risk" including those that are complex and controversial and some that are easy to understand. According to him, risk is multidimensional, as it depends on the financial, physical, ethical, physical, cultural and social factors that influence the role and structure of the organization. The risks arising from these dangers will cause negative impact on teachers and the implementation of the teaching and learning processes outside the classroom. Some teachers are not familiar to conduct the teaching in outdoor environment and are nervous. According to him, sometimes there are logistical problems especially with the trip to the jungle location where failure in communication will result in time delays affecting the time allocated to conduct PeRIMBA.

The teacher's anxiety and fear of the dangers posing a threat to student safety is also a form of risk. Teachers will face a variety of risks in planning and supervising student activities. According to Yilmaz (2016), in schools teachers' concerns about safety are an obstacle for students to gain experience outside of the classroom and indirectly influence parental concerns. Given these concerns, Chakravarthi (2009) and Bundy et al., (2009) state that teachers' safety concerns affect their commitment in teaching. In view of this concern, Marinah \& Norhazwani, (2017) state that teachers' safety concerns affect their commitment to teach and implement PeRIMBA. Connolly \& Haughton (2017) found that public concern over protection of children due to the progress of the world lead to extreme feelings of fear.

The failure to manage PeRIMBA is also due to lack of knowledge and skills in the field (Knight 2010). This is also supported by Stan \& Humberstone (2011), who stated that lack of training and experience may explain why teachers are so concerned about their students safety. In addition, large class sizes and lack of facilities and maintenance of infrastructure and equipment for teaching and learning processes to enable the teaching and learning of the Forest School to be implemented effectively (O'brien, 2011) and in a safe environment (Zimmerman, 2007). The location of the school which is very far inland with the risky school surrounding is one of the obstacles for SK Asli teachers to access this facility especially in the event of accidents and injuries. Figure 4 shows teachers' perceptions of risk in implementing PeRIMBA in SK Asli. 


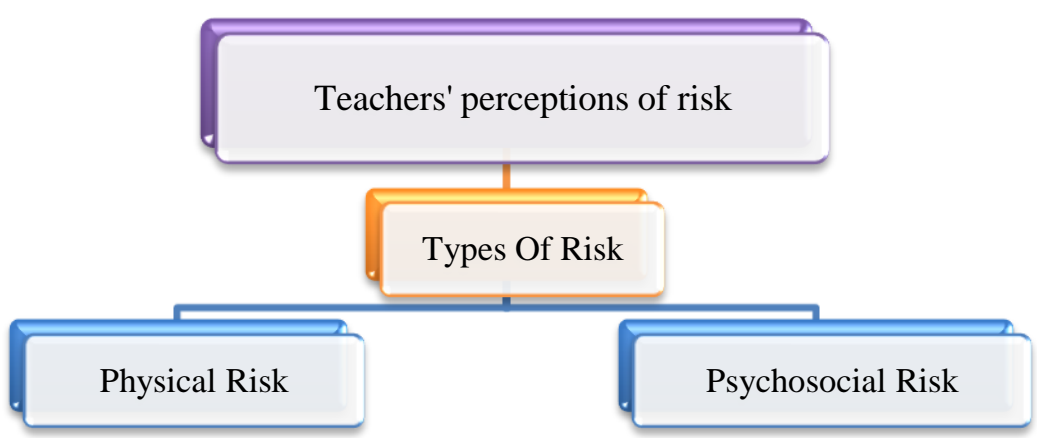

Figure 4: Teachers' perceptions of risk in implementing PeRIMBA in SK Asli.

According to Harris (2017), PeRIMBA activities conducted in the new environment require new rules that are contrary to the norms in the classroom. According to him, being in a new environment would show a change in attitude and behavior. These changes invite teachers to worry about the safety of students exposed to danger. According to him again in the context of teaching that promotes classroom learning, teachers say they are not confident and do not see PeRIMBA being able to support the delivery of the national curriculum despite being recognized for its positive impact through informal teaching (especially in Science, Geography and Language subjects). He also thinks PeRIMBA is often seen as being different from mainstream and informal compared to more formal classroom teaching. As a result, the national curriculum was not a priority in most of the lessons at the Forest School.

\section{Conclusions}

More recently, the Ministry of Education Malaysia has been positively transforming the country's education system. This task requires teachers to be prepared to change the practices of teachers in planning and implementing school program activities, particularly PLBD. In this regard, teachers need to be knowledgeable and skilled in ensuring a safe environment for PeRIMBA to operate. The various forms of risk inherent in the implementation of PeRIMBA are the responsibility of the teacher to evaluate and manage them. According to O'Brien \& Murray, (2007) teachers need to take responsibility if a danger arises and result in accidents and injuries to students when performing activities outside of the classroom.

According to Connolly \& Haughton (2017), the study found that the motivation of these teachers to adopt the PeRIMBA approach derives from the desire to expose students to formative risk taking outside of the classroom. But the notion of society and institutions refusing to take risks and over-protecting children causes their goals to be in line with the needs of an educator, which creates tension in how they want to manage risk if they want to implement PeRIMBA.

\section{Acknowledgments}

This research project was supported by the Fundamental Research Grant Scheme (FRGS) FRGS/1/2019/SS05/IPGM/02/1 'Model Pedagogi Sains Berorientasikan Sekolah Rimba Malaysia dalam kalangan murid Orang Asli', the Ministry of Higher Education, Malaysia.

\section{References}

Coates, J. K., \& Pimlott-Wilson, H. (2019). Learning while playing: Children's Forest School experiences in the UK. British Educational Research Journal.

Connolly, M., \& Haughton, C. (2017). The perception, management and performance of risk amongst Forest School educators. British Journal of Sociology of Education, 38(2), 105-124. https://doi.org/10.1080/01425692.2015.1073098

Harris, F. (2017). The nature of learning at forest school: practitioners' perspectives. International Journal of Primary, Elementary and Early Years Education 3-13, 45(2), 272-291. https://doi.org/10.1080/03004279.2015.1078833

Jacoby, J., Kaplan, L. B., \& Szybillo, G. J. (1974). Components of perceived risk in product purchase: A crossvalidation. Journal of Applied Psychology, 59(3), 287-291. https://doi.org/10.1037/h0036657 
Johnson, B. B. (1993). Advancing Understanding of Knowledge' s Role in Lay Risk Perception of Knowledge 's Role in. Www.Piercelaw.Edu/Risk/Vol14/Summer/Johnson.Html, 4(3).

Marinah, A., \& Norhazwani, S. (2017). Pendekatan Keselamatan dan Kesejahteraan Pelajar untuk SekolahSekolah di Malaysia. Management Research Journal Vol. 7, No. 1 (2017), 139 - 153, 7(1), 139-153.

Maynard, T. (2007). Forest Schools in Great Britain: An Initial Exploration. Contemporary Issues in Early Childhood. https://doi.org/10.2304/ciec.2007.8.4.320

Nordin, M. R. M., \& Ahmad, M. (2015). Pendekatan didik hibur dalam pengajaran dan pembelajaran bahasa melayu: tinjauan terhadap sikap dan minat murid orang asli di negeri perak. Jurnal Penyelidikan Dedikasi, Jilid 9, 2015 PENDEKATAN, 77-90.

Nur Bahiyah, A. W. (2015). Pembangunan Kit Rimba Berorientasikan Elemen Sekolah Rimba Malaysia Bagi Peningkatan Kompetensi Sains Murid Orang Asli. Universiti Teknologi Malaysia.

Nur Bahiyah, A. W., Maryati, M., Azman, H., \& Mohd. Najib, H. (2013). Penerapan Elemen Sekolah Rimba Malaysia Dalam Kalangan Murid Orang Asli. 2nd International Seminar on Quality and Affordable Education (ISQAE).

O'Brien, L., \& Murray, R. (2007). Forest School and its impacts on young children: Case studies in Britain. Urban Forestry and Urban Greening, 6(4), 249-265. https://doi.org/10.1016/j.ufug.2007.03.006

Renn, O. (1998). Three decades of risk research: Accomplishments and new challenges. Journal of Risk Research, 1(1), 49-71. https://doi.org/10.1080/136698798377321

Stan, I., \& Humberstone, B. (2011). An ethnography of the outdoor classroom - how teachers manage risk in the outdoors. Ethnography and Education, 6(2), 213-228. https://doi.org/10.1080/17457823.2011.587360

Waite, S. (2011). Teaching and learning outside the classroom: Personal values, alternative pedagogies and standards. Education 3-13, 39(1), 65-82. https://doi.org/10.1080/03004270903206141

Waite, S., \& Goodenough, A. (2018). What is different about Forest School? Creating a space for an alternative pedagogy in England. Journal of Outdoor and Environmental Education. https://doi.org/10.1007/s42322-017-0005-2

Yilmaz, S. (2016). Outdoor Environment and Outdoor Activities in Early Childhood Education. Mersin Üniversitesi Eğitim Fakültesi Dergisi, 12(1), 423-437. https://doi.org/10.17860/efd.80851 